\title{
1. The Covid-19 shock: the UK national and regional implications in the light of international evidence
}

Philip McCann and Raquel Ortega-Argilés ${ }^{1}$

\section{THE NATURE AND FEATURES OF THE CURRENT PANDEMIC CRISIS}

The immediate impacts of the coronavirus pandemic are very well understood by the population as well as analysts. A health crisis is leading to an economic crisis, and the economic contractions have been much more severe than anyone had anticipated, due to a lack of prior experience of this situation (Smit et al. 2020). The lockdowns which have been instituted by a multitude of countries mean that the global demand for many final goods and services has collapsed and many international supply chains - or more precisely global value-chains - have been stalled. All forms of domestic and international travel have been severely curtailed, global financial markets have rapidly turned into bear markets with only weak growth responses, and in many industrialised countries, the central state has stepped in to differing degrees in order to take over control of whole swathes of the economy, including paying the wages of employees, providing loans for businesses, or even taking ownership stakes in key firms (Anderson et al. 2020; Rothwell and Van Drie 2020). Meanwhile, the share prices have soared for major high-technology firms providing online services and technologies globally, along with many medical, bioscience and pharmaceutical firms involved in critical scientific research.

At this stage, the medium and long-term impacts of these lockdowns have primarily been assessed in terms of their ability to reduce the pandemic contagion, whereas the economic implications are much more difficult to observe or assess. What is certain is that the short-term contractions of both the global economy and almost all national economies will be very serious, but the degree of severity will differ between countries, depending on their economic structures and also the ways in which governments have responded to the pandemic. The forecasts regarding the collapses in demand have tended to become more 
pessimistic as time goes on (IMF 2020; OECD 2020a; EC 2020; World Bank $2020)^{2}$ and most observers agree that these shocks are likely to be more severe than any in living memory. Moreover, predicting the nature of the recovery ${ }^{3}$ is especially difficult because until there is a worldwide vaccine, there remain the fears of future contagion waves and further global lockdowns (Sneader and Singhal 2020). Historical evidence suggests that the more stringent are the lockdown conditions, the more robust will be the subsequent economic recovery (Correia et al. 2020), although some sectors may take several years to recover.

Recovery forecasts span a continuum from the most optimistic to the most pessimistic scenarios, with recovery predictions ranging from a V-shaped recovery, Nike swoosh-stripe type of recovery, a Z-shaped recovery, a W-shaped recovery, a U-shaped recovery, through to an L-shaped recovery, respectively (Sheiner and Yilla 2020). In the UK official forecasts are at the more optimistic end of the spectrum, predicting a $\mathrm{V}$-shaped recovery, whereas most independent forecasts pessimistically expect an L-shaped recovery. ${ }^{4}$ The lack of consensus is largely due to the radical uncertainty context we currently face, which also in part accounts for the dislocation between the emerging underlying economic evidence and the rather more sanguine views of the stock markets, ${ }^{5}$ whose falls do not appear as severe as the economic data might suggest (Griffith et al. 2020).

The patterns of recovery may also differ between countries depending on the scale of the immediate shocks and also on their economic structures. In particular, forecasts suggest that southern and eastern Europe may be especially badly hit in the long run (Doerr and Gambacorta 2020). In the case of southern European countries, this is because of the high dependence on tourism, their high shares of SMEs and their already deeply entrenched labour market problems. In the case of eastern European countries, it is because of low sovereign credit ratings and high export dependency, and in both the southern and eastern European cases it is also because of relatively low shares of workers who are able to work from home via remote working and telecommuting. ${ }^{6}$ The general consensus is that in most countries the pandemic is likely to exacerbate existing labour market divides between higher and lower skilled workers and also between younger and older workers, and between richer and poorer cohorts (Boneva et al. 2020) and this pattern is also expected to hold in the case of the UK (Allas et al. 2020).

At the same time, many global value-chains have faced major pandemic-related disruption, with both demand-side shocks to final goods and services along with lockdown-induced supply-side shocks (Baldwin and Freeman 2020). While the supply chains in sectors such as automobiles were almost entirely shut down, other global supply chains such as food systems 
have managed to remain operational, ${ }^{7}$ even though some dangerous bottlenecks have become evident. ${ }^{8}$

Although it never stopped, the growth of global value-chains (GVCs) had dramatically slowed down in the aftermath of the 2008 crisis, but by 2017 again the growth in GVCs was faster than global economic growth (WTO 2019). Yet, the pandemic shocks may give rise once again to changes in the growth of GVCs, and these major disruptions will impact on both large and small firms alike. In particular, the crisis has spurred some re-thinking around the future nature and resilience (Farrell and Newman 2020) of international minimum inventory supply chains. ${ }^{9}$ Similarly, some commentators have speculated about the possibilities for in-sourcing or near-shoring whereby GVC activities currently undertaken elsewhere can be relocated to newly developed facilities at home. Yet, given the network structure of the global economy, the ability of a country to relocate facilities from overseas to the domestic arena heavily depends on the existing positioning of the network-technological structure of the economy within global trade patterns (Iammarino and McCann 2013). Four decades of deindustrialisation has left the UK heavily exposed in this regard, with little room for manoeuvre. Yet, although almost everything in economics tells us that this is the wrong response (Baldwin and Evenett 2020), there are also risks that the political responses to the pandemic will encourage dangerous movements away from free trade and towards economic nationalism. ${ }^{10}$ Brexit may already be a harbinger of this.

In many countries such as the USA and the UK the pandemic was initially concentrated in the poorer parts of the largest and most densely populated centres (Stier et al. 2020; Frey 2020) such as London, as well as areas dominated by travel and tourism (Muro et al. 2020). Subsequently, the pandemic spread out to other cities and regions (Nathan 2020; Berube 2020), such that after a couple of months, the most severely hit places in the UK were many economically poorer localities ${ }^{11}$ in the more peripheral regions outside of the most prosperous cities. ${ }^{12}$ Yet, as economies slowly emerge from the lockdown, major labour reallocation is likely to occur alongside higher unemployment (Barrero et al. 2020). Some observers consider that the pandemic-induced increases in remote teleworking may permanently reshape how we do business (Guyot and Sawhill 2020; Barrero et al. 2020), ${ }^{13}$ including potentially offering new possibilities for more peripheral locations to attract high wage activities and employees (Muro 2020). Others have speculated about how social distancing may reshape our towns and cities (Tomer and Fishburne 2020), ${ }^{14}$ including questions about the density of future urban development (Fang and Wahba 2020) and the possibly disastrous impacts on much of high street retail markets. ${ }^{15}$ However, before we can identify the likely medium and longer-term implications of Covid-19 for UK cities and regions, it is necessary to consider the current dislocations and shocks in financial markets, because the lesson 
from the 2008 crisis is that these are likely to engender significant and lasting capital reallocation effects throughout the economic system.

\section{PANDEMIC-RELATED SHOCKS TO FINANCIAL AND CAPITAL MARKETS}

In order to begin to map out the likely medium and long-term consequences for UK regions of the pandemic, it is essential first to identify the various short-run responses of the financial and capital markets to the pandemic shocks. This allows us then to map out the likely medium and long-term capital reallocation effects of these short-run responses, and it is these effects which will have profound spatial consequences. Within the UK the nature and patterns of these longer-term reallocation effects are likely to be heavily dependent on international financial shocks due to the highly interconnected global financial markets, as well as on the specific features of the UK urban and regional economic system.

From a capital allocation perspective, there are two key features of the coronavirus pandemic which we need to consider. First, as we have already seen, there are collapsing revenues and supplies in many parts of the global economy as global value-chains have been hugely disrupted, as have the local and global markets for final demand goods and services. This means that many businesses which were perfectly profitable prior to the pandemic will now find themselves insolvent once any government support has ended. Many of these firms will be unable to raise sufficient credit to re-start their businesses once the emergency situation is over and the economy once again begins to pick up. This is because of the huge credit contractions associated with the pandemic.

The huge credit contractions are primarily due to the second key feature of the pandemic, which is to rapidly move the economy from an environment of risk, in which investors are able to ascribe numerical values to risk-return probabilities, to an environment of radical uncertainty, in which this is not possible. Combined with collapsing revenues in many parts of the economy and the fears about another wave of the disease in the coming months, the inability to calculate risks makes it difficult for many investors to price anything, and as such many short-term financial markets have started to contract or seize up entirely. This also means that many medium and long-term investment markets have rapidly contracted or become frozen, given that investment markets inherently are about linking short-term capital activities to medium and longer-term capital actions.

The scale of the turmoil in the global financial markets is almost unprecedented, even when we consider these issues in the light of the 2008 global financial crisis. Although the banking system today is widely perceived to be in much better shape than in $2008,{ }^{16}$ the response of the capital markets has 
been even more severe than in 2008. In March 2020, the level of market panic led to investors dumping US Treasury Bills in favour of cash, ${ }^{17}$ an unprecedented episode in modern financial history. Even the world's safest financial assets were not seen as sufficiently secure or liquid for many investors, and in spite of enormous central bank support, the financial markets have been heavily affected. The markets for many corporate and financial securities have either dried up, or where they are still partially functioning, the yield spreads between higher and lower risk assets have increased dramatically both within and between all types of asset classes (Adrian 2020). ${ }^{18}$

Unlike the 2008 financial crisis, the threats to financial stability now arise primarily from actors outside of the banking system such as asset management and exchange funds in which investment managers aim to liquidate more risky investments quickly, leading to greater option-implied volatility and retreats from riskier or higher yield investments (Ernst 2020). This means that all forms of risky investments have become riskier and less attractive, relative to safer assets with the result that most companies are now facing higher funding costs from equity and corporate bond markets. The manifestations of these shocks include cutbacks in international bank lending, ${ }^{19}$ expansive mergers and acquisitions have largely ground to a halt, ${ }^{20}$ major credit downgrades for corporates have spiralled, ${ }^{21}$ venture capital markets are in retreat, ${ }^{22}$ and share buybacks have been dramatically reduced. ${ }^{23}$ Only a small number of superstar corporates have been able to build up significant reserves to protect themselves. ${ }^{24}$ In addition, the yield spreads across countries are also rising, making it harder for weaker countries to finance their increased deficits and debts and putting pressure on the stability of the Eurozone. ${ }^{25}$

Out of this market turmoil, amongst market players, there are likely to be many 'losers' and some 'winners', some of which we can already identify. Apart from the sectors which are the most directly hit by the crisis, such as retail, hospitality, transport, travel and tourism (OECD 2020b) and many areas of manufacturing, these shocks in the financial markets will have specific adverse impacts on several broad generic areas of the economy, namely the SMEs - small and medium-sized enterprises (OECD 2020c), and the real estate and economic development industry of cities (OECD 2020d).

The withdrawal of all forms of business credit and investment funding, including venture capital, will be especially severe for small and medium-sized enterprises (SMEs). The firms in this sector, many of which are financially fragile (Bartik et al. 2020), are likely to be especially squeezed for two reasons. First, they will be squeezed from below as the general availability of credit is reduced, and second, they will be squeezed from above because many larger firms which are typically much less reliant on bank funding will be seeking bank funding, especially where they have faced credit downgrades. ${ }^{26}$ Many countries have implemented emergency schemes to try to protect their 
SME sectors during the lockdown, but the fact that these were designed in a hurry means that many of these have faced major teething problems, ${ }^{27}$ and large numbers of SMEs in various countries have still failed to access emergency funding. Some firms are attempting to agree 'coronavirus clauses' in their dealing with banks in an attempt to access more credit by allowing lockdown-related foregone earnings to be included in revenue calculations, but lenders are loath to do this as this increases the risks for investors. ${ }^{28}$ In spite of these unprecedented policy interventions, it still remains likely that significant parts of the SME sectors in all economies will be wiped out by the crisis, and this is especially concerning for those countries which are particularly reliant on SMEs, such as Mediterranean countries. In the UK, the highly centralised banking system means that SMEs in weaker regions, and in particular innovative SMEs, are likely to face particularly severe credit constraints, as was the case after the 2008 crisis (Mayer et al. 2021).

A second segment of the market which is likely to face severe problems is the real estate industry. The movement towards radical uncertainty and temporarily frozen markets has meant that it is impossible for dealers to value or price investments or for independent valuers to provide accurate and reliable valuations of underlying assets. ${ }^{29}$ Many UK property funds have been suspended. ${ }^{30}$ Similarly, real estate investment trusts (REITs), which specialise in buying mortgage-backed securities, have faced falling values for the bonds they offer for collateral to the banks on which they depend. As fears for the ability of unemployed homeowners to repay their mortgages escalate, the REITs are being forced to sell their bonds to raise further cash in an already declining market. Moreover, the fact that real estate transactions are temporarily frozen also means that the ability of the central banks to stimulate aggregate demand via lower interest rates is also greatly weakened, due to the inability of households to refinance (Goodman and Klein 2020). In the UK the number of mortgage products available had halved between early March and early April 2020 , and the mortgage products removed by lenders from the market were largely those which allowed for high loan-to-value ratios and imposed few restrictions on the sources and forms of incomes acceptable to secure the mortgage.$^{31}$ As such, even though central bank rates are at their historically lowest levels, the ability of these to bring about an increase in household economic activity is very limited. The combined result of all of these effects will be to stymie the real estate and urban development industry. Many new or proposed economic development projects will be put on the back-burner, mothballed or even cancelled, and even some which are already underway will be truncated mid-development. The high street, in particular, is likely to be severely hit in many weaker cities and towns as investors move away from commercial developments. ${ }^{32}$ Where activity is taking place it is likely to be in land-banking. ${ }^{33}$ 
In terms of the possible winners within the capital markets, the private equity buyout industry has been one of the big winners since the 2008 crisis as debt has been cheap and money has flowed into private equity coffers. ${ }^{34}$ As well as 'big tech' firms, ${ }^{35}$ some private equity firms will also gain greater acquisition leverage from the market falls, ${ }^{36}$ although their acquisitions of cheaper assets will be to some extent limited by scarce financing. Many private equity firms depend on capital committed by long-term institutional investors such as pension funds and insurance companies, so this should enable many of them to ride out the current storm. It is estimated that private equity firms hold some $\$ 2.5$ trillion in investment capital as well as acquiring large corporations. Over recent years the debt-focused private equity firms have taken over from banks as the major suppliers of credit to medium-sized firms, especially in the travel, leisure and tourism sectors, as well as investing in areas such as real estate and infrastructure. ${ }^{37}$ In the current climate, the shocks faced by these sectors, allied with falling asset prices and high levels of gearing, mean that even some private equity firms will be vulnerable to the downturn. ${ }^{38}$ In contrast, many others will move away from these more risky sectors and assets in tourism and real estate and instead will move towards the purchase of higher-quality assets and premium companies. In addition, some hedge funds, and especially the larger ones, ${ }^{39}$ will have benefitted from the market volatility, but many hedge funds are also seeing outflows of capital due to equity sell-offs and widening credit spreads, impacting more severely on smaller hedge funds.

In general, however, all of these capital market trends suggest that in many sectors monopoly positions are likely to increase, and in spatial terms greater levels of monopoly tend to imply higher regional divergence. The greater presence of central government in all aspects of the economy will also tend to imply greater divergence, especially in centralised states. Finally, the higher yield spreads between and within asset classes will tend to be manifested between regions with weaker riskier regions facing even higher yields relative to prosperous places. The effect of which is likely to increase spatial partitioning in terms of the capital-intensity and income elasticities of the goods and services locally produced (Saffie et al. 2020), thereby driving further regional divergence. As such, in terms of spatial markets, all of these capital market and fiscal effects will tend to favour core locations at the expense of more risky and weaker locations (Garrote Sanchez et al. 2020). This is likely to be the experience of many countries, including the UK. In addition, sectors and localities in which relatively few workers can work remotely, which are heavily dependent on SMEs, and which also have significant tourism industries, are all likely to be heavily exposed to post-Covid economic shocks. At an EU-wide scale, the evidence points to severe shocks to regions in southern and eastern Europe (Doerr and Gambacorta 2020) and a widening of the gaps between the 
economic core and periphery, and this already has spurred the proposal of key new initiatives supporting nations and regions. ${ }^{40}$

\section{THE UK REGIONAL IMPLICATIONS OF CORONAVIRUS}

In the early stages of the crisis, there was no clear geographical pattern to the medium or long-term economic impacts of the pandemic across UK regions (Enenkel 2020; Davenport et al. 2020). However, the effects of unemployment, business failures, supply chain ruptures and occupational types are all interacting in specific ways, and as the pandemic has progressed, a clearer pattern of these likely impacts has emerged.

In the short run, locations with higher shares of professional and white-collar workers whose occupations and work roles better allow them to work remotely throughout the crisis, were seen as being likely to be economically hit much less than the locations with higher shares of blue-collar workers (Magrini 2020), and these short-term patterns are likely to be carried over into medium and long-term patterns (Barrero et al. 2020). The emerging evidence points to the economically weaker regions of the UK being the most adversely affected by the coronavirus shock (Innes et al. 2020; Scott 2020), while coastal tourism-dependent towns will have also suffered sharp contractions (CFT 2020). In contrast, the services sectors of London are likely to be the least affected sectors in the medium and long term (Davenport et al. 2020). ${ }^{41}$ Major UK employers in sectors such as aerospace, automobiles, transportation and retail have already announced widespread redundancies, and these shocks will continue to spill over to SMEs in their supply chains. Indeed, there is already early evidence of substantial increases in the number of firms dissolving in March 2020 compared with March 2019, with sectors such as Transport and Storage, Professional, Scientific and Technical Activities and Wholesale and Retail sectors facing particularly difficult times (Prashar et al. 2020). In addition, there is a noticeable sharp increase in dissolutions of very new firms less than two years old, and in spatial terms, the West Midlands and Wales show the largest relative increases in SME dissolutions. Many SMEs will fail to pay back their 'bounceback loans', 42 and these broad effects on SMEs are in line with the capital market issues outlined above.

Rising yields and falling asset values in economically weaker localities will increase the relative risks faced by all investors in these areas including local governments, and these localised risk factors will also be exacerbated to the extent that local authorities have previously taken financial positions in local real estate developments. ${ }^{43}$ Not surprisingly, the UK local authorities rated as the riskiest areas facing the largest likely economic hits (Norman 2020) are mostly in the non-core regions of the UK, and especially in the midlands and 
the north of England. ${ }^{44}$ Moreover, people in large cities and towns in northern England and Wales have the highest household debt and are likely to be the most severely hit by the economic downturn (Narayan 2020). Moreover, their ability to service these debts will decline as yield values and collateral requirements increase disproportionately in these localities. As such, the pandemic shocks overall are likely to exacerbate the UK's existing interregional inequalities and to move directly against the 'levelling up' agenda. ${ }^{45}$

Huge declines in UK commercial office demand ${ }^{46}$ suggest that many firms will be looking to reduce their city-centre presence either by allowing more home-working or shifting back-office functions elsewhere. Barrero et al. (2020) predict that there will a permanent increase in home-working to some 20 per cent of all office hours beyond those already worked at home, and this may increase the reach and buoyancy of the hinterland of prosperous cities. Yet, these same reduced office-demand trends, allied with further shifts towards online retail, may jeopardise the rebuilding of the core parts of the economically weaker cities and towns (LDC 2020), thereby weakening some of the agglomeration-led city regeneration agenda and widening both the UK's inter-urban and as well as the inter-regional inequalities (Carrascal-Incera et al. 2020). The combination of Covid-19 and Brexit (Billing et al. 2019) are likely to make the 'levelling up' agenda even harder than before.

\section{NOTES}

1. The research of Raquel Ortega-Argilés was funded by Research England (UKRI) as part of the West Midlands Regional Economic Development Institute (WMREDI) grant at the University of Birmingham, Project ID 724390

2. "Global Economic Outlook Still Worsening, Says IMF”, Financial Times, 12 May 2020

3. "How the Economy Will Look After the Coronavirus Pandemic", Foreign Policy, 15 April 2020

4. "UK Economy Faces 5\% Annual Deficit by 2024, Say Economists", Chris Giles, Financial Times, 27 May 2020

5. "A Dangerous Gap: The Market v the Real Economy", The Economist, 7 May 2020; "Investors Baffled by Soaring Stocks in 'Monster' Depression", Financial Times, 20 April 2020

6. "Picking off the Weak: How Deep Will Downturns in Rich Countries Be? Those in Central and Southern Europe Seem Most Vulnerable", The Economist, 16 April 2020; "Covid-19 Hits Greece Harder than the Rest of the Eurozone: A Terrible Toll on Tourism", The Economist, 11 April 2020; "Into the Trough: Eastern Europe's Covid-19 Recession Could Match its Post-Communist One", The Economist, 27 May 2020

7. "Keeping Things Cornucopious: The World's Food System has so far Weathered the Challenge of Covid-19", The Economist, 9 May 2020

8. "Daily Chart: The Spread of Covid has Caused a Surge in American Meat Prices", The Economist, 13 May 2020; "Farmers Warn over Food Supply with Harvest 
Workers Shut Out”, Financial Times, 27 March 2020; “"Chaotic and crazy': Meat Plants around the World Struggle with Virus Outbreaks", The Guardian, 11 May 2020

9. "Pandemic Strains Shipping, Air and Rail Freight Operators", Financial Times, 22 May 2020

10. "China-US Rivalry and Threats to Globalisation Recall Ominous Past", Martin Wolf, Financial Times, 26 May 2020

11. “Coronavirus: Which Regions Have Been Worst Hit?”, BBC, 9 June 2020, https:// www.bbc.co.uk/news/52282844

12. "Coronavirus UK Map: The Latest Deaths and Confirmed Cases in Each Region", The Guardian, 28 May 2020; Joint PHE Modelling Cell, and MRC Biostatistics Unit COVID-19 Working Group, Paul Birrell, Joshua Blake, Edwin van Leeuwen, Daniela De Angelis, 10 May 2020, https://www.mrc-bsu.cam.ac.uk/now-casting/; "Deprived Areas Hit Hardest in UK by Pandemic", Financial Times, 1 May 2020

13. "Bartleby: Working Life has Entered a New Era", The Economist, 28 May 2020

14. "How Life in Our Cities Will Look After the Coronavirus Pandemic", Foreign Policy, 1 May 2020; "Perspectives: Covid-19 Might Not Change Cities as Much as Previous Pandemics", The Economist, 25 April 2020

15. "Inside London: Gap between Retail Winners and Losers Widens to a Chasm", Financial Times, 23 May 2020

16. “This Time we're Different. How Sick Might Banks Get? They Have Entered this Crisis in Better Health than the Previous One", The Economist, 15 April 2020

17. Adam Tooze, "How Coronavirus Almost Brought Down the Global Financial System", The Guardian, 14 April 2020; "How Did Covid-19 Disrupt the Market for US Treasury Debt?", Financial Times, 1 May 2020

18. "The Cash Crisis: Why America's Financial Plumbing Has Seized Up. Central-Bank Action is Failing to Stem the Rout", The Economist, 21 March 2020

19. "US Banks Pull Back from Lending to European Companies", Financial Times, 24 April 2020

20. "Dealmaking Grinds to a Halt on Coronavirus Impact", Financial Times, 31 March 2020; "End of Heady Dealmaking Leaves Banks Fretting Over 'Turkeys"”, Financial Times, 23 March 2020

21. "Downgrades Flood Junk Bond Market With 'Fallen Angels"', Financial Times, 7 April 2020; "Global Oil Pact and Fed Support Boost Junk-Rated US Bond Market”, Financial Times, 14 April 2020

22. "Asia's Largest Companies Try to Sell Down Stakes in Start-Ups", Financial Times, 31 March 2020; "Hottest Silicon Valley Start-Ups Begin to Sell Themselves at a Discount", Financial Times, 1 May 2020

23. "Stock Buybacks Expected to Halve as Companies Bolster Defences", Financial Times, 7 April 2020; "Perspectives: In Many Ways, Stockmarkets have Been Extraordinary in 2020", The Economist, 3 May 2020

24. "Top-Rated Companies Raise \$1tn in 5 Months to Fill 'War Chests", Financial Times, 26 May 2020

25. "ECB Warns of Challenge for Eurozone from Soaring Public Debt", Financial Times, 26 May 2020

26. "Riskier European Companies Draw $€ 32$ bn from Bank Credit Lines", Financial Times, 27 May 2020; "Riskiest US Companies are Left Behind in Rush to Buy Debt", Financial Times, 26 June 2020

27. "Averting Nightmare on Main Street: Politicians in America and Europe Scramble to Help Small Firms", The Economist, 2 May 2020 
28. “Corona Clause Creeps into Businesses' Loan Documents", Financial Times, 18 March 2020

29. "Wave of UK Property Funds Suspended Trapping £13bn of Investor Cash", Financial Times, 18 March 2020

30. "Wave of UK Property Funds Suspended Trapping £13bn of Investor Cash", Financial Times, 18 March 2020

31. "UK Property Market Moves into Cold Storage”, Financial Times, 9 April 2020

32. "Like a Ton of Bricks: Is Investors' Love Affair With Commercial Property Ending?", The Economist, 25 June 2020

33. "Taylor Wimpey to Raise $£ 500 \mathrm{~m}$ for Land Buying Offensive”, Financial Times, 17 June 2020

34. "Private Equity Wants a Hand from Taxpayers", Financial Times, 24 April 2020

35. "Big Tech Goes on Pandemic M\&A Spree Despite Political Backlash", Financial Times, 28 May 2020

36. "Private Equity Firms Target Dealmaking Opportunities amid Turmoil", Financial Times, 18 March 2020

37. "Private Equity Firms Target Dealmaking Opportunities amid Turmoil", Financial Times, 18 March 2020

38. "Private Equity Wants a Hand from Taxpayers", Financial Times, 24 April 2020

39. "Hedge Funds: No Market for Small Firms", Financial Times, 19 May 2020

40. "ECB Agrees to Inject Additional $€ 600 \mathrm{bn}$ into Eurozone Economy", The Guardian, 4 June 2020

41. "Levelling-Up and COVID-19”, KPMG Chief Economist's Note, 22 April 2020, See: https://home.kpmg/uk/en/home/insights/2020/04/chief-economist-s-note-le velling-up-and-covid-19.html

42. "UK Banks Warn $40 \%-50 \%$ of Bounce Back Borrowers Will Default", Financial Times, 31 May 2020

43. "Councils' Outgoings are Rocketing and Revenues Collapsing", The Economist, 2-8 May 2020; "English Councils Poised to Make Cuts Amid Loss of Commercial Income", The Guardian, 13 July 2020

44. “COVID-19 Local Area Risk Rating", 28 April 2020, See: https://www.progressive -policy.net/covid-19-local-area-risk-rating-april-28

45. "Dealing with the Virus: How Covid-19 Exacerbates Inequality", The Economist, 26 March 2020

46. "Will London's Newest Skyscraper Become a Monument to the Market Peak?", Financial Times, 29 May 2020

\section{REFERENCES}

Adrian, T., 2020, "Monetary and Financial Stability During the Coronavirus Outbreak", IMF Blog, International Monetary Fund, 11 March, See: https://blogs.imf.org/2020/ 03/11/monetary-and-financial-stability-during-the-coronavirus-outbreak/

Allas, T., Canal, M., and Hunt, V., 2020, "COVID-19 in the United Kingdom: Assessing Jobs at Risk and the Impact on People and Places", 11 May, See: https:// www.mckinsey.com/industries/public-sector/our-insights/covid-19-in-the-united -kingdom-assessing-jobs-at-risk-and-the-impact-on-people-and-places

Anderson, J., Bergamini, E., Brekelmans, S., Cameron, A., Darvas, Z., and Domínguez Jíménez, M., 2020, "The Fiscal Response to the Economic Fallout from the 
Coronavirus", Bruegel, 25 April, See: https://www.bruegel.org/publications/ datasets/covid-national-dataset/

Baldwin, R.E., and Evenett, S.J. (eds), 2020, COVID-19 and Trade Policy: Why Turning Inward Won't Work, CEPR and Vox.EU Publishing, See: https://voxeu.org/ content/covid-19-and-trade-policy-why-turning-inward-won-t-work

Baldwin, R., and Freeman, R., 2020, "Supply Chain Contagion Waves: Thinking Ahead on Manufacturing 'Contagion and Reinfection' from the COVID Concussion", VOX CEPR Policy Portal, 1 April, https://voxeu.org/article/covid-concussion-and-supply -chain-contagion-waves

Bartik, A.W., Bertrand, M., Cullen, Z.B., Glaeser, E.L., Luca, M., and Stanton, C.T., 2020, "How are Small Businesses Adjusting to Covid-19? Early Evidence from a Survey", NBER Working Paper 26989, National Bureau of Economic Research, See: http://www.nber.org/papers/w26989

Barrero, J-M., Bloom, N., and Davis, S.J., 2020, "COVID-19 is also a Reallocation Shock", Brookings Papers on Economic Activity, BPEA Conference Draft, 25 June

Berube, A., 2020, "Which City Economies did COVID-19 Damage First?", 29 April, See: https://www.brookings.edu/blog/the-avenue/2020/04/29/which-city-economies -did-covid-19-damage-first/?utm_campaign $=$ Brookings $\% 20$ Brief\&utm_source $=\mathrm{hs}$ email\&utm_medium $=$ email\&utm_content $=87187919$

Billing, C., McCann, P., and Ortega-Argilés, R., 2019, "Interregional Inequalities and UK Sub-National Governance Responses to Brexit", Regional Studies, 53.5, $741-760$

Boneva, T., Goli, M., and Rauh, C., 2020, "Inequality in the Impact of the Coronavirus Shock: Evidence from Real Time Surveys", Abi Adams-Prassl, IZA Discussion Paper, No. 13183, April

Carrascal-Incera, A., McCann, P., Ortega-Argilés, R., and Rodriguez-Pose, A., 2020, "UK Interregional Inequality in a Historical and International Comparative Context", National Institute Economic Review, 2020, Forthcoming

CFT, 2020, "The Effect of the COVID-19 Pandemic on our Towns and Cities", Centre for Towns, See: https://www.centrefortowns.org/reports/covid-19-and-our-towns

Correia, S., Luck, S., and Verner, E., 2020, "Pandemics Depress the Economy, Public Health Interventions Do Not: Evidence from the 1918 Flu", 10 April, See: https:// www.gsb.stanford.edu/sites/gsb/files/fin_04_20_verner.pdf

Davenport, A., Farquharson, C., Rasul, I., Sibieta, L., and Stoye, G., 2020, "The Geography of the COVID-19 Crisis in England", Institute for Fiscal Studies, See: https://www.ifs.org.uk/uploads/The-Geography-of-the-COVID19-crisis-in-England -final.pdf

Doerr, S., and Gambacorta, L., 2020, "Covid-19 and Regional Employment in Europe”, BIS Bulletin No 16, Bank of International Settlements, 15 May, See: https://www .bis.org/publ/bisbull16.htm

Enenkel, K., 2020, "What Does the COVID-19 Crisis Mean for the Economies of British Cities and Large Towns?", Centre for Cities, 16 April, See: https://www .centreforcities.org/blog/what-does-the-covid-19-crisis-mean-for-the-economies-of -british-cities-and-large-towns/

Ernst, E., 2020, "The Return of the Fourth Horseman: How the Current Pandemic Might Reshape our World”, Ekkehard Ernst, 30 March, See: https://medium.com/ @ekkehard_ernst/the-return-of-the-fourth-horseman-how-the-current-pandemic -might-re-shape-our-world-4f82d7f8eac4

European Commission (EC), 2020, European Economic Forecast, Institutional paper 132, July, Publications Office of the European Union, Luxembourg 
Fang, W, and Wahba, S., 2020, "Urban Density Is Not an Enemy in the Coronavirus Fight: Evidence from China", 20 April, See: https://blogs.worldbank.org/sustainable cities/urban-density-not-enemy-coronavirus-fight-evidence-china

Farrell, H., and Newman, A., 2020, "Will the Coronavirus End Globalization as We Know It? The Pandemic Is Exposing Market Vulnerabilities No One Knew Existed", Foreign Affairs, March 16, See: https://www.foreignaffairs.com/articles/2020-03 -16/will-coronavirus-end-globalization-we-know-it

Frey, W.H., 2020, "Who Lives in the Places Where Coronavirus is Hitting the Hardest?", Brookings, 10 April, See: https://www.brookings.edu/blog/the-avenue/ 2020/04/10/who-lives-in-the-places-where-coronavirus-is-hitting-the-hardest/?utm _campaign=brookings-comm\&utm_source=hs_email\&utm_medium=email\&utm content $=86280769$

Garrote Sanchez, D., Gómez Parra, N., Özden, C., and Rijkers, B., 2020, "Which Jobs are Most at Risk Because of COVID-19?", Brookings, 18 May, See: https:// www.brookings.edu/blog/future-development/2020/05/18/which-jobs-are-most-at -risk-because-of-covid-19/?utm_campaign=brookings-comm\&utm_medium=email \&utm_content $=88511391 \&$ utm_source $=$ hs_email

Goodman, L., and Klein, A., 2020, "The Impacts of the Coronavirus on Mortgage Refinancings", Brookings Series on Financial Markets and Regulation, 13 April, See: https://www.brookings.edu/research/the-impact-of-the-coronavirus-on-mortg age-refinancings/

Griffith, R., Levell, P., and Stroud, R., 2020, "The Impact of COVID-19 on Share Prices in the UK", IFS Briefing Note BN276, 27 March

Guyot, K., and Sawhill, I.V., 2020, "Telecommuting will Likely Continue Long after the Pandemic", Brookings, 6 April, See: https://www.brookings.edu/blog/up-front/ 2020/04/06/telecommuting-will-likely-continue-long-after-the-pandemic/?utm_ca mpaign=Economic\%20Studies\&utm_source=hs_email\&utm_medium $=$ email\&utm content $=85974745$

Iammarino, S., and McCann, P., 2013, Multinationals and Economic Geography: Location, Technology and Innovation, Edward Elgar, Cheltenham, UK and Northampton, MA, USA

IMF, 2020, World Economic Outlook Update: A Crisis Like No Other: An Uncertain Recovery, International Monetary Fund, June, Washington DC

Innes, D., McDonald, R., and Bennett, S., 2020, “Targeted Action for Parts of Britain at Risk of Surging Unemployment", See: https://www.jrf.org.uk/blog/targeted-action -parts-britain-risk-surging-unemployment

LDC, 2020, "The Impact of Covid-10 on UK Town and City Centres", Local Data Company, 30 April, See: https://www.localdatacompany.com/blog/the-impact-of -covid-19-on-towns

Magrini, E., 2020, "How Will Coronavirus Affect Jobs in Different Parts of the Country?", Centre for Cities, See: https://www.centreforcities.org/blog/how-will -coronavirus-affect-jobs-in-different-parts-of-the-country/

Mayer, C., McCann, P., and Schumacher, J., 2021, "The Structure and Relations of Banking Systems: The UK Experience and the Challenges of "Levelling-Up", Oxford Review of Economic Policy, Oxford University Press, Oxford, Forthcoming

Muro, M., 2020, "Could Big Tech's Move to Permanent Remote Work Save the American Heartland”, 26 May, See: https://www.brookings.edu/blog/the-avenue/ 2020/05/26/could-big-techs-move-to-permanent-remote-work-save-the-american -heartland/?utm_campaign=Brookings\%20Brief\&utm_medium=email\&utm_con 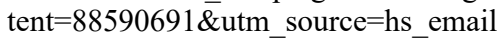 
Muro, M., Maxim, R., and Whiton, J., 2020, "The Places a COVID-19 Recession Will Likely Hit Hardest”, Brookings, 17 March, See: https://www.brookings.edu/blog/ the-avenue/2020/03/17/the-places-a-covid-19-recession-will-likely-hit-hardest/?ut m_campaign $=$ brookings-comm\&utm_source $=$ hs_email\&utm_medium $=$ email\&ut m_content $=84875880$

Narayan, K., 2020, "Household Debt and Problem Debt in British Cities", 23 April, See: https://www.centreforcities.org/wp-content/uploads/2020/04/Household-debt -and-problem-debt-in-British-cities-1.pdf

Nathan, M., 2020, "The City and the Virus", Medium, 14 May, See: https://medium .com/@maxnathan/the-city-and-the-virus-db8f4a68e404

Norman, A., 2020, "Which Local Authorities Face the Biggest Immediate Economic Hit?", 16 April, See: https://www.progressive-policy.net/publications/which-local -authorities-face-biggest-immediate-economic-hit

OECD, 2020a, OECD Economic Outlook June 2020, Organisation for Economic Co-operation and Development, Paris

OECD, 2020b, Tourism Policy Responses to the coronavirus (COVID-19), Updated 2 June, Organisation for Economic Co-operation and Development, Paris

OECD, 2020c, Coronavirus (COVID-19): SME Policy Responses, Updated 19 May, Organisation for Economic Co-operation and Development, Paris

OECD 2020d, Cities Policy Responses, Updated 13 May, Organisation for Economic Co-operation and Development, Paris

Prashar, N., Ri, A., Hart, M., and Roper, S., 2020, "Business Dynamism and Covid-19: An Early Assessment”, ERC Insight Paper, Enterprise Research Centre, April, See: https://www.enterpriseresearch.ac.uk/wp-content/uploads/2020/04/ERC-Insight-Bu siness-Dynamics-and-COVID-19-FINAL.pdf

Rothwell, J., and Van Drie, H., 2020, "The Effect of COVID-19 and Disease Suppression Policies on Labor Markets: A Preliminary Analysis of the Data", 27 April, See: https://www.brookings.edu/research/the-effect-of-covid-19-and-disease -suppression-policies-on-labor-markets-a-preliminary-analysis-of-the-data/?utm _campaign $=$ Economic\%20Studies\&utm_source $=$ hs_email\&utm_medium $=$ email\& utm_content $=87099641$

Saffie, F., Varela, L., and Yi, K-M., 2020, "The Micro and Macro Dynamics of Capital Flows”, CEPR Discussion Paper DP14893, Centre for Economic Policy Research, London

Scott, P., 2020, "Local Data Reveals the Boroughs 'Left Behind' by the Government's Covid-19 Response", New Statesman, 21 July, See: https://www.newstatesman .com/politics/2020/07/local-data-reveals-boroughs-left-behind-government-s-covid -19-response

Sheiner, L., and Yilla, K., 2020, "The ABCs of the Post-COVID Economic Recovery", Monday, 4 May, See: https://www.brookings.edu/blog/up-front/2020/05/04/the-ab cs-of-the-post-covid-economic-recovery/

Smit, S., Hirt, M., Buehler, K., Lund, S., Greenberg, E., and Govindarajan, A., 2020, "Safeguarding our Lives and our Livelihoods: The Imperative of our Time", McKinsey and Company, March

Sneader, K., and Singhal, S., 2020, "Beyond Coronavirus: The Path to the Next Normal", 2020, McKinsey and Company, March

Stier, A.J., Berman, M.G., and Bettencourt, L.M.A., 2020, "COVID-19 Attack Rate Increases with City Size", See: https://ssrn.com/abstract=3564464

Tomer, A., and Fishburne, L., 2020, "Big City Downtowns are Booming, But Can their Momentum Outlast the Coronavirus?", Adie Tomer and Lara Fishburne, 6 May, 
See: https://www.brookings.edu/research/big-city-downtowns-are-booming-but-can -their-momentum-outlast-the-coronavirus/?utm_campaign=Metropolitan\%20Policy $\% 20$ Program\&utm_source $=h$ h_email\&utm_medium $=$ email\&utm_content $=878754$ 05

World Bank, 2020, Global Economic Prospects: June 2020, Washington DC WTO, 2019, "Technological Innovation, Supply Chain Trade, and Workers in a Globalised World: Global Value Chain Development Report”, 2019, World Trade Organization, Geneva, See: https://www.wto.org/english/res_e/booksp_e/gvc_dev _report_2019_e.pdf 